\title{
DOIS FRAGMENTOS CÔMICOS SOBRE A TRAGÉDIA
}

I - Antífanes, fr. 189, de Poesia: Compor tragédias é moleza!

Arte afortunada é a tragédia, em tudo! Para começar, o enredo

é conhecido dos espectadores antes mesmo de se abrir a boca, de modo que ao poeta

basta apenas recordar. Se falar "Édipo", somente, tudo o mais eles sabem: o pai é Laio;

a mãe, Jocasta; quem são as filhas e os filhos;

o que sofrerá e o que fez. E se, por sua vez, disser "Alcmeon", tudo as criancinhas já acabaram de recitar: que, tomado de loucura, matou a mãe, e que Adrasto, agastado, logo chegará e de novo partirá. E, depois, sempre que não têm mais nada a dizer e se exaurem inteiramente em suas peças, [os poetas trágicos], como quem pede água, erguem o deus ex-machina e isso satisfaz os espectadores!

Para nós, [poetas cômicos], não é assim, mas, ao contrário, tudo

é preciso inventar: nomes novos, e, em seguida, a ação pregressa, a situação presente, o desfecho, a introdução. Caso omita uma dessas partes um Cremes ou um Fídon, ele é expulso pelas vaias, mas a Peleu ou Teucro tudo se permite fazer.

II - Tímocles, fr. 6, de As mulheres que celebram as Dionísias:

Para que serve a tragédia?

Meu senhor, escute, se lhe pareço ter algo a dizer!

O ser humano é um animal que nasce para sofrer 
e a vida comporta muitas tristezas.

Ele inventou, então, o seguinte alívio para as preocupações.

A mente, uma vez que esquece seus próprios sofrimentos

e é seduzida pelos dos outros,

parte com prazer, além de instruída também.

Para começar, se quiser, examine como os poetas trágicos

ajudam todo o tipo de gente. O que é pobre,

ao saber que Télefo é mais indigente do que ele,

já suporta com mais facilidade a pobreza.

$\mathrm{O}$ que padece de alguma loucura considera Alcmeon.

Um sofre dos olhos? Os Fineidas são cegos.

Está morto o filho de outro? Níobe serve de alívio.

Um é manco? Olha para Filoctetes.

Um velho é abandonado pela sorte... Ele aprende sobre Eneu.

Todos os infortúnios, os maiores que qualquer um sofreu, ao perceber-se que se tornam de outros, lamenta-se menos as suas próprias desgraças.

\section{Notas}

I - Antífanes viveu no sec. IV a. C. e é um nome de destaque entre os poetas da comédia intermediária ou média, constando na Suda que tenha alcançado treze vitórias ao longo de sua carreira. Nenhuma de suas peças sobreveio na íntegra, mas são conhecidos cerca de 300 fragmentos e 138 títulos de comédias a ele atribuídas. O fragmento traduzido acima é da comédia Poesia (Poíesis). Nele, um poeta cômico se queixa do quão dura é a sua tarefa quando equiparada às facilidades de que os poetas trágicos desfrutam, sobretudo por ser o mito, matéria prima da tragédia, conhecido de antemão pelos espectadores que, desse modo, poderiam suprir lacunas decorrentes de falhas de composição. $\mathrm{O}$ fragmento foi preservado por Ateneu, no Banquete dos Sábios (Deipnosophistaí, 6. 222a-223a). Para tradução, segui o texto que integra a antologia coligida por Douglas Olson (Boken Laughter. Select Fragments of Greek Comedy. Oxford: Oxford University Press, 2007).

v. 01 arte: em grego está poíema, obra de poesia, gênero poético.

v. 05 Édipo: Além de Sófocles, vários tragediógrafos compuseram peças sobre o herói e seus descendentes, inclusive Ésquilo e Eurípides, de modo que sua história era bem conhecida dos espectadores. Por isso é de se esperar que, 
além de sua árvore genealógica, saibam que mutilará os olhos e partirá em exílio (v. 8, "o que sofrerá") e que matara inadvertidamente o pai, desposando em seguida a mãe (v. 8, "o que fez").

v. 09 Alcmeon: Sófocles, Eurípides e vários outros poetas compuseram tragédias sobre este herói que, instigado pelo pai, Anfiarau, matou sua mãe, Erífile, suspeita de atraiçoá-los. Foi, por isso, perseguido pelas Erínias, perdendo a razão até ser purificado da morte. Participou, junto com Adrasto, do segundo ataque contra Tebas, na expedição conhecida como a dos Epígonos.

v. 15 Pede água: em grego literalmente "levanta o dedo", aludindo ao código adotado pelos lutadores de boxe ou pancrácio para reconhecer a derrota e sinalizar a desistência.

v. 22 Cremes ou Fídon: nomes genéricos e recorrentes de personagens cômicas.

v. 23 Peleu ou Teucro: Peleu, o pai de Aquiles, e Teucro, o irmão de Ájax, representam as personagens típicas da tragédia, ou seja, os heróis do mito.

II - Tímocles atuou na metade final do séc. IV a. C. e compôs comédias no estilo intermediário e novo. Foram preservados 42 fragmentos seus e vinte e sete títulos de comédias. Tem-se notícia de que obteve ao menos uma vitória. $\mathrm{O}$ fragmento traduzido acima é da comédia As Mulheres que celebram as Dionísias (Dionysiazoúsais), também citado por Ateneu, em o Banquete dos Sábios (Deipnosophistaí, 6. 223b-c), logo na sequência do trecho de Antístenes, e por Estobeu (IV. 56.19). Nele argumenta-se em favor da utilidade da tragédia como consolo para os males. O poeta ressalta também o caráter didático do gênero (v. 7,), que vai de par com seu lado lúdico. Mais uma vez segui o texto que apresenta Douglas Olson (Boken Laughter. Select Fragments of Greek Comedy. Oxford: Oxford University Press, 2007).

v. 10 Télefo: herói árcade, filho de Héracles. Torna-se rei da Mísia e aliado dos troianos, sendo ferido por Aquiles durante a Guerra de Troia. Como a ferida não cicatrizasse, disfarça-se de mendigo e, aconselhado por um oráculo, parte em busca do herói grego para obter a cura. Infiltrado entre os gregos, é descoberto e toma Orestes, ainda menino, como refém, de modo a persuadir os inimigos a ouvi-lo. Ésquilo, Eurípides e Agatão, além de outros tragediógrafos, compuseram tragédias sobre ele. Aristófanes parodiou o Télefo de Eurípides em duas oportunidades (Acarnenses, 325-556, e As tesmoforiantes, 466-764), enfatizando o aspecto miserável da personagem. 
v. 12 Alcmeon: cf. nota ao v. 09 do fragmento anterior.

v. 13 Fineidas: Filhos do adivinho Fineu, ele próprio cego, os Fineidas teriam perdido a visão em decorrência da perseguição de sua madrasta, Ideia. Aristóteles menciona uma tragédia de mesmo nome na Poética (1455a 10), cuja autoria é desconhecida, mas lá se refere a filhas de Fineu.

v. 14 Níobe: Filha de Tântalo e mulher de Anfíon, com quem teve entre dez e quatorze filhos, metade de cada sexo. Por ter se vangloriado de parir mais filhos do que Leto, Apolo e Ártemis, vingando sua mãe, mataram os Nióbidas com suas flechas. Ésquilo e Sófocles teriam composto tragédias sobre ela.

v. 15 Filoctetes: Antes de chegar a Troia, onde lutaria ao lado dos gregos, o herói fora picado por uma serpente e, como a ferida exalasse um odor pútrido, Odisseu convence seus companheiros a abandoná-lo a própria sorte em uma ilha. Tiveram que voltar para buscá-lo dez anos mais tarde, após a revelação que Troia somente cairia se as armas de Héracles, de que Filoctetes era detentor, estivessem em posse do exército grego. Além de Sófocles, cujo Filoctetes esta preservado, Ésquilo e Eurípides também teriam dedicado peças ao herói.

v. 16 Eneu: Rei de Cálidon e o primeiro a cultivar o vinho, como sugere seu nome (oineús, vinicultor). Na velhice é maltratado por seus sobrinhos, que lhe usurpam o trono. É defendido por seu neto Diomedes ou por Tideu, seu filho. Consta um Eneu dentre os títulos de tragédias atribuídas a Eurípides.

Traducão de ADRIANE DA SILVA DUARTE Faculdade de Filosofia, Letras e Ciências Humans Universidade de São Paulo 